\title{
MEASURABLE AND UNMEASURABLE FEATURES OF ULTRASOUND LYMPH NODE IMAGES IN DETECTION OF MALIGNANT INFILTRATION
}

\author{
Tatjana Rotim ${ }^{1}$, Branka Kristek ${ }^{1}$, Tajana Turk ${ }^{1}$, Domagoj Kretić ${ }^{1}$, Marija Perić ${ }^{\text {, }}$ \\ Ivo Pušeljić ${ }^{1}$ Tijana Pandurović ${ }^{1}$ and Mario Stefanićc ${ }^{3}$
}

${ }^{1}$ Department of Diagnostic and Interventional Radiology, ${ }^{2}$ Department of Clinical Cytology, Osijek University Hospital Center; ${ }^{3}$ Department of Nuclear Medicine and Oncology, School of Medicine, Josip Juraj Strossmayer University of Osijek, Osijek, Croatia

SUMMARY - The aim of the study was to assess diagnostic value and utility of selected morphological features in predicting lymph node (LN) malignancy using B-mode, Doppler ultrasonography and multivariate settings in a tertiary radiological referral center. The study included 123 patients having undergone ultrasound-guided fine-needle aspiration and cytologic analysis (FNAC) of cervical, axillary and inguinal LNs. Each LN was characterized by long/L and short/T-axis, shape, margins, echogenicity, cortical thickness, vascularization, and examiner's subjective impression. Within the limitations of FNAC, altered shape and vascularization had relatively high specificity and positive predictive value $(>80 \%)$, whereas subjective impression had high sensitivity and negative predictive value (100\%) for malignancy. The cut-off levels for different features of LN by ROC analysis were as follows: long-axis $23 \mathrm{~mm}$, short-axis $11 \mathrm{~mm}, \mathrm{~L} / \mathrm{T}$ ratio 2.19 , and maximal cortical thickness $5.1 \mathrm{~mm}$. On multivariate analysis (adaptive regression splines, $\mathrm{n}=108$ ), the addition of long-axis, $\mathrm{L} / \mathrm{T}$ ratio, age and sex considerably improved diagnostic accuracy (88\%), sensitivity (margins + vascularization) and specificity (subjective impression) of the diagnostic model. The combination of morphological and demographic features could improve diagnostic accuracy, usually with a trade-off between the sensitivity and specificity of the predictive model. The performance may depend on the level of expertise and institutional settings.

Key words: Lymph nodes - abnormalities; Ultrasonography, doppler; Biopsy, fine-needle; Cytodiagnosis; Predictive value of tests; Croatia

\section{Introduction}

Malignant neoplasms are among the leading causes of mortality in the world. In 2012, 14.1 million new cases and 8.2 million new deaths from malignant disorders were registered ${ }^{1,2}$. Data for Croatia show high incidence and high mortality, making cancer the second most common cause of death in Croatia ${ }^{3}$.

Correspondence to: Tatjana Rotim, $M D$, Department of Diagnostic and Interventional Radiology, Osijek University Hospital Center, Josipa Huttlera 4, HR-31000 Osijek, Croatia

E-mail: tatjana.rotim@gmail.com

Received April 19, 2017, May 15, 2017
Radiology plays a central role in individual tailoring of therapeutic decisions in oncology. Besides the location and extension of primary tumor, the existence of metastases in distant or draining lymph nodes (neck, armpits and groin) is one of the most important factors in staging of malignant disease.

For lymph node (LN) diagnosis, several methods are available including clinical examination, ultrasonography (US), computerized tomography (CT), magnetic resonance imaging, US-guided cytologic aspiration, and positron emission tomography (PET/CT) $)^{4,5}$.

Ultrasonography is often the examination of choice in the evaluation of LNs, whereby LN is described by 
several quantitative and semi-qualitative morphological features. The longitudinal (L) and transverse (T) diameter is measured, and the shape of the $\mathrm{LN}$ is judged by the L/T ratio, usually taken as the limit value of 2 or 1.5. The hilum is hyperechoic in normal LN, and cortical thickness is 1 to $2 \mathrm{~mm}$. The cortex is considered to be thickened when it is more than half of the cross diameter of the hilum. The margins can be regular, irregular, or poorly delimited. The internal structure is described by echogenicity, whereas vascularization is mostly described as hilar, peripheral, or avascular $^{6-8}$.

None of these features or their alteration, taken as a single criterion, is reliable, sensitive or specific enough to suspect or refute malignancy. A combination of morphological features can more accurately characterize the nature of $\mathrm{LN}^{4}$; however, the results often differ by anatomic region, clinical settings, type of malignancy, golden standard, level of expertise and demographics. When combined with guided fine needle aspiration and cytologic analysis (FNAC), or with surgical removal and histopathology of the entire node, it is nevertheless considered a safe, reliable and widely accepted method of real-time evaluation of peripheral LNs, even in clinically silent nodes ${ }^{9-11}$.

The aim of the present study was to extend the existing knowledge on the diagnostic value of US morphological features in predicting peripheral LN malignancy by using multivariate approach to address independent predictors, their utility and sources of variations affecting diagnostic performance and $\mathrm{LN}$ morphology. The ultimate goal was to enable pursuit of less invasive methods in $\mathrm{LN}$ diagnosis.

\section{Patients and Methods}

This prospective observational study was conducted at Department of Diagnostic and Interventional Radiology, Osijek University Hospital Center, Osijek, Croatia, from December 13, 2013 to April 7, 2015. The survey included 123 participants of both genders and all age groups (range 11-86 years) referred for US examination of the neck, armpits and groin with an indication for US-guided FNAC of LN. Patients presented for regular check-ups due to the known malignancy or were referred by clinicians or family physicians due to palpable LN of uncertain causes.
The LNs in the neck, armpits and groin were surveyed by examination. Indication for US-guided FNAC was set according to radiological guidelines including palpable, enlarged and/or morphologically altered LNs.

\section{Ultrasonography}

All ultrasound examinations ( $\mathrm{B}$ mode and color Doppler) were performed upon review of medical records by a board-certified radiologist (TR) with 8-year experience, using a linear $5-13 \mathrm{MHz}$ probe under small-parts settings (Aloka ProSound Digital Color System, Hitachi Ltd., Tokyo, Japan). The examination was done in supine position, in case of the neck in mild hyperextension (about 45 degrees), by visualizing the longitudinal and transverse section. Flow Doppler US study was analyzed using the following optimized Doppler parameters: low wall filter to show slow flow rates $(50-100 \mathrm{~Hz}$ ), low speed scale (about $5 \mathrm{~cm} / \mathrm{s}$ ) and low repetition frequency pulsating $\mathrm{PRF}$ with high sensitivity to show slow flow $(700-1000 \mathrm{~Hz})$. Color-gain was optimized individually for better display and less artifacts.

Using US and flow, each LN was rated with 8 parameters, as follows: I) regional location (neck, axilla, groin); II) dimension in transverse and longitudinal orientation of the LN [longitudinal (L) and transverse (T) diameter]; III) shape (taking into account the $\mathrm{L} / \mathrm{T}$ ratio of the $\mathrm{LN}$ ): oval, round, irregularly shaped; IV) margins (regular, irregular); V) echogenicity (hyperechoic central portion with hypoechoic, thickened cortex; hypoechoic, heterogeneous); VI) cortical thickness (in millimeters); VII) vascularization by color Doppler US (regular - from the hilum to the periphery, irregular - hypervascularized, hypovascularized, irregularly vascularized); and VIII) subjective impression of the $\mathrm{LN}$ as a semi-qualitative indicator based on the experience of the examiner (benign, malignant, suspicious $\mathrm{LN}$ with possible malignancy).

\section{Ultrasound-guided FNAB}

After skin disinfection (Skinsept color, Ecolab GmbH\&Co., OHG, Germany) and visualization of the LN with the US probe at an angle of 90 degrees in relation to the lesion, puncture was made with a 21-gauge LB needle (MEDOJECT, Slovak Republic) attached to a 10 or $20 \mathrm{~mL}$ syringe. The needle was in- 
serted along the longer or shorter side of the US transducer. After the needle had entered the LN, the syringe plunger was pulled, whereby negative pressure was created and the contents of the LN were aspirated. The needle was moved within the LN 10-20 times. Upon completion, the piston was returned to the initial position and negative pressure was relieved, thereby reducing the possibility of tumor cell migration along the needle's path. The needle was then withdrawn out of the body. The radiologist did both FNA and smears. During the study, no significant complication of the methods described was recorded.

\section{Cytology}

The mounted glass slides were air-dried and then stained by May-Grünwald-Giemsa at the Department of Clinical Cytology, Osijek University Hospital Center, Osijek, Croatia. The binocular light microscope (Olympus BX 40 CY) with x100, x200, x400 and x1000 magnification was used to classify samples as benign or malignant.

The criteria for benignity included: I) normal nucleocytoplasmic ratio; II) small nucleoli; III) limited number of nucleoli; IV) smooth nuclear membrane; V) fine chromatin; VI) absence of hyperchromasia; VII) tightly adherent cells (except for LNs); VIII) clear background; and IX) absence of mitosis.

The criteria for malignancy included: I) disrupted nucleocytoplasmic ratio; II) prominent nucleoli, increased in size, with irregular configuration; III) an increased number of nucleoli; IV) irregular nuclear membrane; V) nuclear hyperchromasia; VI) coarse chromatin; VII) decreased cell adherence; VIII) necrosis; and IX) mitotic figures.

For adequate sample, it was important to have a sufficient number of lymphoid cells for the diagnosis. The samples with a small number of lymphoid cells and with plentiful peripheral blood cells were marked as insufficient for the diagnosis. In case of benign cytologic results, the US and FNAB were repeated after 4-8 weeks. In patients with cytologic confirmation of malignancy and unknown primary cancer diagnostic work-up was continued. Patients with malignant cytologic findings and prior oncologic diagnosis received further oncologist attention.

\section{Ethics}

The Ethics Committee of the Osijek University Hospital Center reviewed and approved the study pro- tocol (No. 25-1:15401-7/2013) in accordance with the provisions of the Helsinki Declaration of 1975, as revised in 1983. Informed consent in written form was obtained from all participants prior to enrollment.

\section{Statistics}

Data were expressed as medians with interquartile range or absolute and relative frequencies where applicable. Fisher, Pearson $\chi^{2}$, Mann-Whitney and Kruskal-Wallis test with post-hoc Bonferroni-Dunn's assessment were used for independent group comparisons, depending on the scale of the measure. For sparse contingency tables, empirical p-values were estimated by 10000 Monte Carlo simulations. Areas under the receiver operating characteristic curves (ROC) and the best cut-off values (Youden index), along with sensitivity and specificity, negative predictive value (NPV) and positive predictive value (PPV) were calculated. Friedman's multivariate adaptive regression splines $^{12}$ (MARS), a flexible nonparametric form of stepwise regression analysis that makes no assumptions about the underlying functional relationship, was used to evaluate the independent significance of predictive factors (earth package ${ }^{13}$ for $\mathrm{R}$ software $^{14}$ v. 3.3.2). MARS is particularly useful for high-dimensional problems, complex structures and fitting general nonlinear multivariate functions. The best model was chosen as the one with the lowest generalized cross validation criterion value (penalty $=3$ ). As a result, MARS tends to produce simple and easy-to-interpret low order models, since it heavily penalizes model complexity. The predictive performance was assessed by flexible discriminant analysis ( $m d a \mathrm{R}$ package $\left.{ }^{15}\right)$, using MARS basis function to predict class membership (FNA cytology). Two-tailed p-values of $<0.05$ were considered significant. Unless otherwise stated, all tests were performed using the IBM SPSS Statistics v. 19 software.

\section{Results}

\section{Descriptive analysis}

A total of 123 LNs in 64 male and 59 female participants of similar age [median 58 (45-71) years] were analyzed. Repeated US and FNA cytology yielded 108 (88\%) informative (46 benign and 62 malignant) and 15 suspicious/indeterminate cytologic findings in con- 
trol interval. Among malignantly altered LNs, metastatic carcinomas $(n=34)$, lymphoproliferative disease $(n=22)$ and metastatic malignant melanoma $(n=3)$ were most frequent; among benign LNs, reactive hyperplasia $(n=25), \mathrm{LN}$ tissue $(\mathrm{n}=16), 2$ granulomatous and 1 suppurative inflammation were recorded. Fifty (41\%) participants had a known history of malignant neoplasm. In women, benign cytologic findings were more frequent (29/59); by contrast, malignant cytologic diagnoses were more frequent in men (40/64, $\mathrm{p}=0.017$ ), with an equal number of suspicious findings. By region, 63 (51\%) LNs were classified as cervical, 35 $(28 \%)$ as inguinal, and the rest were located in the axillae. Higher proportions of cervical (59\%) and axillary LNs (31\%) were observed in men and women, respectively $(\mathrm{p}=0.022)$. The prevalence of malignant cytologic findings did not vary by location. The participants with benign LN cytology were significantly younger than patients with malignant LN cytology [53 (40-64) vs. 64 yrs (51-73) yrs; $\mathrm{p}=0.012$, Kruskal-Wallis test, Dunn-Bonferroni post hoc].

\section{Ultrasonographic features of lymph nodes}

\section{Morphometry}

The cytologically malignant and suspicious LNs had a significantly greater longitudinal [L: 22 (16-29) and $20(16-26) \mathrm{mm}$, respectively] and transverse diameter [T: 13 (10-18) and $11(9-18) \mathrm{mm}$ ] compared to the benign LNs [L: 17 (14-22) mm, p=0.0025; T: 8 (6-11) $\mathrm{mm}, \mathrm{p}=10^{-6}$, Kruskal-Wallis test]. The benign LNs had a significantly higher $\mathrm{L} / \mathrm{T}$ ratio compared to the malignant ones [2.2 (1.6-2.7) vs. $1.6(1.3-2)$, $\mathrm{p}=0.0002)$, Kruskal-Wallis test]. On univariate analysis, cervical LNs had a significantly lower $\mathrm{L} / \mathrm{T}$ ratio as compared with inguinal LNs [1.6 (1.3-2.1) vs. 2.1 (1.7-2.5), p=0.02, Kruskal-Wallis test]. The cytologically malignant LNs showed a higher maximal cortical thickness [7.1 (6.2-7.8) mm, n=15, p=0.03, MannWhitney test], but with a considerable overlap with the benign LNs [4.1 (3.1-7.3) mm, $\mathrm{n}=30$ ].

\section{Qualitative lymph node echo-characteristics}

There were no robust gender differences in the distribution of qualitative morphological features. In the neck region, cytologically malignant $\mathrm{LNs}$ were predominantly heterogeneous and hypoechoic (33/37). Axillary and inguinal LNs with the echoic central portion-thickened cortex and hypoechoic LNs were equally frequent among malignantly altered $\mathrm{LNs}$, with a smaller share of heterogeneous LNs. Inguinally, the cytologically benign LNs most often had echoic central portion with thickened cortex (14/16). In other regions, LNs with the echoic central portion and thickened cortex were as common as hypoehoic LNs among benign LNs. Heterogeneous LNs were rare in the benign cytology group ( 1 inguinal LN, within the limitations of FNAC).

In total, in all regions, regardless of cytology, oval LNs were most frequent, particularly axillary (23/25) and inguinal (31/35 LN). Irregular (6/123) and rounded LNs (19/123) were exclusively and almost exclusively associated with the neck region (6/6 and 13/19 LNs, respectively, $\mathrm{p}=0.046)$ and malignant cytology.

According to the examiner's subjective impression, LNs were depicted as benign $(n=29)$, malignant $(n=46)$ and suspicious of malignancy $(\mathrm{n}=48)$. The participant age $(\mathrm{p}=0.00011)$, longitudinal $(\mathrm{p}=0.0006)$ and transverse diameter $\left(\mathrm{p}<10^{-6}\right.$, Kruskal-Wallis test), shape $(\mathrm{p}<0.001)$, echogenicity $(\mathrm{p}<0.001)$ and vascularization $\left(\mathrm{p}<0.001, \chi^{2}\right.$-test $)$ were significantly associated with subjective impression on univariate analysis. The examiner's impression did not convincingly vary according to gender $(\mathrm{p}=0.076)$, history of malignancy $(\mathrm{p}=0.056)$ or anatomic region $\left(\mathrm{p}=0.072, \chi^{2}\right.$-test $)$.

\section{Lymph node cytology}

The distribution of qualitative US features of the LNs according to cytologic status is shown in Table 1. The cytologically malignant LNs were usually oval in shape and benign. The majority of rounded LNs were cytologically characterized as malignant (15/17 LNs with informative cytology). LNs were rarely irregularly shaped, and then were typically of malignant cytology. Both benign and malignant LNs usually had regular margins. Irregular margins were a less common finding, usually in conjunction with malignant cytology (19 out of 21 LNs with informative cytology). Lobular margins were equally often found in both malignant and benign LNs. Cytologically malignant LNs (32/62) were more often hypoechoic; by contrast, a central echoic hilum with thickened cortex was a common finding in the benign cytology group (31/46). A significant portion of malignant LNs fell within this group (15/62), as well as a significant portion of benign LNs within the hypoechoic group (14/46). Het- 
Table 1. Distribution of ultrasonographic lymph node features according to cytologic status

\begin{tabular}{|c|c|c|c|c|c|}
\hline \multirow{2}{*}{ Characteristic } & \multirow{2}{*}{ Category } & \multirow{2}{*}{$\mathrm{p}^{*}$} & \multicolumn{3}{|c|}{ Cytology } \\
\hline & & & Benign & Malignant & Suspicious \\
\hline \multirow[t]{3}{*}{ Shape } & Oval & & 44 & 42 & 12 \\
\hline & Round & 0.014 & 2 & 15 & 2 \\
\hline & Irregular & & 0 & 5 & 1 \\
\hline \multirow[t]{3}{*}{ Margins } & Regular & & 38 & 35 & 11 \\
\hline & Irregular & $<0.001$ & 2 & 19 & 3 \\
\hline & Lobular & & 6 & 8 & 1 \\
\hline \multirow[t]{3}{*}{ Echogenicity } & $\begin{array}{l}\text { Hyperechoic central portion } \\
\text { with thickened cortex }\end{array}$ & & 31 & 15 & 5 \\
\hline & Hypoechoic & $<0.001$ & 14 & 32 & 9 \\
\hline & $\begin{array}{l}\text { Heterogeneous, mostly } \\
\text { hypoechoic }\end{array}$ & & & 15 & 1 \\
\hline \multirow[t]{4}{*}{ Vascularization } & $\begin{array}{l}\text { From the hilum to the } \\
\text { periphery }\end{array}$ & & 40 & 23 & 6 \\
\hline & Hypervascularized & $<0.001$ & 2 & 13 & 1 \\
\hline & Hypovascularized & & 0 & 10 & 4 \\
\hline & Irregularly vascularized & & 4 & 16 & 4 \\
\hline \multirow[t]{3}{*}{ Impression } & Benign & & 27 & 0 & 2 \\
\hline & Suspicious & $<0.001$ & 18 & 23 & 7 \\
\hline & Malignant & & 1 & 39 & 6 \\
\hline
\end{tabular}

* $\chi^{2}$-test, empirical p-value, 10000 Monte Carlo simulations

erogeneous LNs were almost exclusively malignant by cytology (15/16 LNs with informative findings), although a relatively small number of malignant $\mathrm{LNs}$ were heterogeneously structured. Benign LNs were predominantly vascularized from the hilum towards the periphery (40/46 benign LNs). Malignant $\mathrm{LN}_{\mathrm{s}}$ showed a wide range of vascular patterns, the most common being the one from the hilum towards the periphery. Altered vascularization was moderately to highly predictive of malignant cytology (13/16 hypervascularized, 10/14 hypovascularized and 16/24 irregularly vascularized LNs), but had only moderate sensitivity (39 of 62 malignant LNs).

The correspondence between final cytology and subjective impression varied by gender: in women, the impression of suspicious LN was more often associated with benign LN cytology than in men (14/27 vs. $4 / 21$, Fisher exact $\mathrm{p}=0.04$ ). The $\mathrm{LN}$ s deemed suspicious by the examiner's subjective impression were the principal source of false positives (18/19 LNs with informative cytology). By contrast, false negatives seldom appeared; as a proof of concept, $98 \%$ of cytologi- cally malignant $\mathrm{LNs}$ ( $\mathrm{n}=61$ ) showed at least one morphological alteration (shape, margins, echogenicity, vascularization, $L>19 \mathrm{~mm}$, short axis $>11 \mathrm{~mm}$ ).

\section{Predictive value}

Diagnostic value for suspicious nodal characteristics was estimated using reference categories, selected according to the prevailing echo-characteristics of benign LNs (oval shape, regular margins, regular vascularization, echoic central portion with thickened cortex, benign impression). Only the participants with informative cytology were included in the analysis (benign/malignant) (Table 2).

Two end-groups of predictors were noticed: one characterized by a relatively high specificity and PPV (shape, margins, vascularization) and the other by high sensitivity and NPV (subjective impression). Diagnostic accuracy varied from approximately $60 \%$ of correctly classified LNs (shape, margins) through 73\% (echogenicity, vascularization) to $82 \%$ (subjective impression).

For quantitative morphometric characteristics and age, the ROC analysis was performed (Table 3, Fig. 1). 
Table 2. Lymph node characteristics and their diagnostic value

\begin{tabular}{|l|l|l|l|l|l|}
\hline Parameter & Shape & Margins & Echogenicity & Vascularization & Impression \\
\hline Sensitivity (\%) & $32(21-45)^{*}$ & $44(31-57)$ & $76(63-86)$ & $63(50-75)$ & $100(93-100)$ \\
Specificity (\%) & $96(85-99)$ & $83(69-92)$ & $67(52-80)$ & $87(74-95)$ & $59(43-73)$ \\
PPV (\%) & $91(71-98)$ & $77(63-87)$ & $75(67-83)$ & $87(75-93)$ & $77(70-83)$ \\
NPV (\%) & $51(47-56)$ & $52(46-58)$ & $67(56-77)$ & $63(55-71)$ & 100 \\
\hline
\end{tabular}

*95\% confidence interval; $\mathrm{PPV}=$ positive predictive value; $\mathrm{NPV}=$ negative predictive value

Table 3. Receiver-operating-characteristic curve analysis of quantitative morphometric characteristics and age

\begin{tabular}{|l|l|l|l|l|l|}
\hline Characteristic & $\begin{array}{l}\text { Area under } \\
\text { curve }\end{array}$ & $\mathrm{p}$ & $\begin{array}{l}\text { Best cut-off* } \\
(\text { Sens, Spec) } \%\end{array}$ & $80 \%$ Sensitivity & $80 \%$ Specificity \\
\hline $\begin{array}{l}\text { Longitudinal } \\
\text { diameter (L) }\end{array}$ & 0.67 & 0.002 & $\begin{array}{l}23 \mathrm{~mm} \\
(48,80)\end{array}$ & $16 \mathrm{~mm}$ & $23 \mathrm{~mm}$ \\
\hline $\begin{array}{l}\text { Transverse } \\
\text { diameter (T) }\end{array}$ & 0.8 & $<0.001$ & $\begin{array}{l}11 \mathrm{~mm} \\
(71,74)\end{array}$ & $9 \mathrm{~mm}$ & $13 \mathrm{~mm}$ \\
\hline $\begin{array}{l}\text { Max. cortical } \\
\text { thickness }\end{array}$ & 0.7 & 0.03 & $\begin{array}{l}5.1 \mathrm{~mm} \\
(87,67)\end{array}$ & $6.1 \mathrm{~mm}$ & $7.4 \mathrm{~mm}$ \\
\hline L/T ratio & 0.74 & $<0.001$ & $\begin{array}{l}2.19 \\
(89,50)\end{array}$ & 2.08 & 1.5 \\
\hline Age (yrs) & 0.66 & 0.004 & $69(44,85)$ & 50 & 67 \\
\hline
\end{tabular}

*Youden index; Sens = sensitivity; Spec = specificity

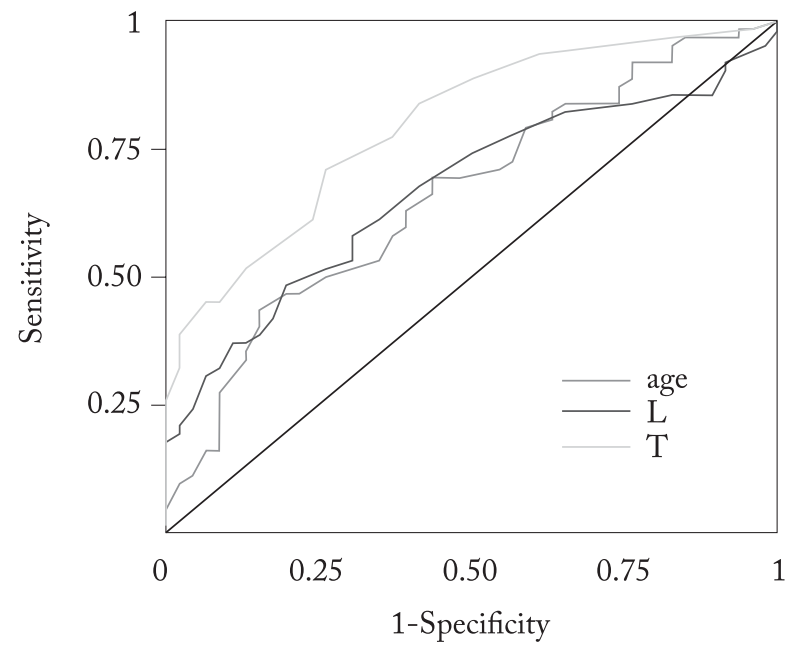

Fig. 1. Receiver-operating-characteristic curve analysis; longitudinal $(L)$ and transverse $(T)$ diameter of the lymph node and age at examination $(n=108)$.

Due to the limited diagnostic value of individual parameters, diagnostic value of their combinations was also estimated using the multivariate approach. For each set of predictors, an associated MARS model was generated. The classification result of the flexible discriminant analysis for each regression model (confusion matrix) was used to assess the predictive values of the models/variables (Table 4).

Among the combinations of the independent, quantitative morphometric predictors and demographic variables (model $\mathrm{M} 1$ ), gender, age, $\mathrm{L} / \mathrm{T}$ ratio and long-axis diameter were sufficient for correct classification of 88 (81\%) of the LNs analyzed.

By combining qualitative nodal characteristics, subjective impression was the only significant predictor of cytology in the additive model (M2a). Excluding subjective impression, margins and vascularization (model M2b, Table 4) were the only remaining independent predictors of FNAC, with 87 (81\%) accurately classified LNs. In both cases (M1, M2), a higherorder model with pair-wise interactions did not improve diagnostic value of the additive model.

The predictive value for the combination of significant demographic characteristics, morphometric variables (M1) and qualitative features (M2b) is given in 
Table 4. Evaluation of diagnostic value, combined variables (flexible discriminant analysis, multivariate adaptive regression splines, penalty $=3$, backward method)

\begin{tabular}{|l|l|l|l|l|l|l|l|l|}
\hline \multirow{2}{*}{ Parameter } & \multicolumn{7}{|c|}{ Model } \\
\cline { 2 - 9 } & M1 & $\beta$ & M2b & $\beta$ & M3 & $\beta$ & M4 & $\beta$ \\
\hline Predictors & Sex-male & 0.47 & Margins-irreg & 0.67 & Margins-irreg & 0.64 & Impression-mal & 1.79 \\
& L/T ratio-2.7 & 0.79 & Hypervasc & 1.19 & Hypervasc & 0.8 & Susp x Mal & 1.1 \\
& Age-27 (y) & 0.013 & Hypovasc & 1.23 & Hypovasc & 0.83 & Susp x (age-50 y) & 0.038 \\
& L-13 (mm) & 0.036 & Irreg vasc & 0.85 & Irreg vasc & 0.65 & Susp x (1.52-L/T ratio) & 1.91 \\
& Intercept & -1.59 & Intercept & -0.57 & L/T ratio-2.7 & 0.46 & Intercept & -0.98 \\
& & & & & L-13 (mm) & 0.034 & & \\
& & & & & Intercept & -1.1 & & \\
\hline Sensitivity (\%) & $85(74-93)^{*}$ & & $77(65-87)$ & & $87(76-94)$ & & $90(80-96)$ & \\
\hline Specificity (\%) & $70(54-82)$ & & $85(71-93)$ & & $89(76-96)$ & & $83(69-92)$ & \\
\hline PPV (\%) & $79(71-86)$ & & $87(77-93)$ & & $92(82-96)$ & & $88(79-93)$ & \\
\hline NPV (\%) & $78(65-87)$ & & $74(63-82)$ & & $84(73-91)$ & & $86(75-93)$ & \\
\hline
\end{tabular}

*95\% confidence interval; $\beta=$ regression coefficient, Hypervasc = hypervascularized; Hypovasc = hypovascularized; Irreg = irregular; $\mathrm{L}=$ longitudinal diameter; $\mathrm{T}=$ transverse diameter; $\mathrm{Mal}=$ malignant; $\mathrm{Susp}=$ suspicious impression; $\mathrm{PPV}=$ positive predictive value; $\mathrm{NPV}=$ negative predictive value

Table 4 (M3, additive model, $88 \%$ accuracy). For the higher-order model based on subjective impression (M1+M2a, M4), age (knot/cut off 50 years), male sex and $\mathrm{L} / \mathrm{T}$ ratio (cut-off 1.52 ) significantly increased the specificity, mostly through reclassification of suspicious LNs. However, a trade-off between diagnostic accuracy of the final model (M4, 87\% correctly classified LNs) and sensitivity was noted. Interestingly, $5 / 6$ false negatives belonged to lymphoproliferative disorders.

The small number of hematologic versus non-hematologic malignancies precluded any further analysis of diagnostic performance by cancer type.

\section{Discussion}

In the present study, the LNs of interest were situated primarily in the neck, then in the groin, and finally in the axillae. It has been previously shown that of all peripheral LNs, cervical LNs were most commonly identified by both physicians and patients. In addition, over fifty percent of lymphadenopathies have been located in the head and neck region ${ }^{16-18}$.

The long-axis and the short-axis diameters were increased in malignantly altered LNs by FNAC. Similar findings have been previously reported for malignant cervical LNs ${ }^{19,20}$. By contrast, although malignant LNs are usually larger than reactive ones, the reactive $\mathrm{LNs}$ can also be as large ${ }^{21}$. Different studies used different cut-off values for the short-axis diameter in order to better distinguish malignant from benign nodes. It has also been argued that a higher cut-off value reduces the sensitivity but increases the specificity, and vice vers $a^{4,5,19,22,23}$. In addition, regional variations and agedependent histoarchitectural changes in human LNs have also been described.

In our study, the LNs with malignant cytology were mostly oval, as well as benign LNs. The majority of rounded and irregularly shaped LNs were malignant by FNAC, an observation consistent with the previously reported studies ${ }^{8,23-25}$. Nevertheless, it has been reported that normal submandibular and parotid nodes, as well as the LNs related to some non-malignant diseases such as tuberculosis ${ }^{7}$, are often round ${ }^{26,27}$. It has been well established that malignant LNs may have an oval shape in the early developmental stage ${ }^{26}$.

The shape of the $\mathrm{LN}$ is determined by its $\mathrm{L} / \mathrm{T}$ ratio. Different $\mathrm{L} / \mathrm{T}$ ratios have been used to predict malignancy ${ }^{7}$. A T/L ratio of $>0.5^{28}$ and $\mathrm{L} / \mathrm{T}$ ratio under 1.5 or $2^{7}$ have been often used for this purpose. We confirmed the $\mathrm{L} / \mathrm{T}$ ratio to be significantly lower in malignant LNs; however, there was a high overlap with benign LNs. In close agreement, Podkrajsek et al. have suggested that the $\mathrm{L} / \mathrm{T}$ ratio is the most reliable crite- 
rion to predict metastases in axillary LNs. However, with a cut-off value of 1.2 , the sensitivity was $46 \%$, and the specificity $91 \%{ }^{29}$.

Regular margins are frequently found in both benign and malignant LNs. Nevertheless, irregular margins have also been reported in benign, as well as in malignant superficial cervical LNs ${ }^{7,27,30}$. We found that irregular margins had high specificity, but much lower sensitivity in predicting LN malignancy. Similar findings have been reported for metastatic cervical $\mathrm{LNs}^{30,31}$.

The benign LNs (by FNAC) typically had hyperechoic hilum and thickened cortex, and were vascularized from the hilum to the periphery. The cytologically malignant LNs were mostly hypoechoic or heterogeneously structured, particularly in the neck region; however, the absence of echoic hilum was not diagnostic of malignancy ${ }^{29,30}$. Hereby, heterogeneous LNs were almost exclusively malignant by FNAC, although relatively few malignant $\mathrm{LNs}$ appeared heterogeneous. Similarly, heterogeneous echostructure was found to be highly suspicious of malignancy in a study of cervical $\mathrm{LNs}^{30}$, with high sensitivity and specificity of $79 \%$ and $92 \%$, respectively ${ }^{30}$.

In our study, the cytologically malignant LNs showed significantly higher maximal cortical thickness compared to cytologically benign LNs. Similar findings have been reported for metastatic melanoma, as well as for breast cancer and metastatic underarm LNs. In those studies, cortical thickening of more than 3.8 $\mathrm{mm}$ was associated with $56 \%$ sensitivity and $92 \%$ specificity for metastatic disease ${ }^{21,32,33}$. Here, an overall diagnostic performance of cortical thickness appeared limited, with a similar trade-off between the specificity and sensitivity at the best cut-off value.

The cytologically malignant LNs often showed normal vascularity, followed by various patterns of altered vascularization. When present, altered vascularization had a relatively high specificity and PPV for malignant FNAC. The presence of peripheral blood vessels, irregularities and mixed vascularization in the LN has been considered a useful indicator of malignancy in many studies. Peripheral and dislocated vascularization, compared to the metastases without detectable flow, has been considered an indicator of earlier stages of metastatic changes ${ }^{34-36}$.

Roughly, two groups of individual predictors could be observed: one characterized by a relatively high specificity and PPV, but low diagnostic accuracy (shape, margins, vascularization); and the other by high sensitivity, NPV and moderate-to-high accuracy (subjective impression). The diagnostic power of the latter most likely reflects its synthetic nature, by cumulating the information on morphological alterations across the score of individual predictors: as a proof of concept, $98 \%$ of the cytologically malignant LNs showed at least one morphological alteration. The level of expertise, learning curves and institutional settings may all affect this process; however, demographics, prior history of malignancy, cancer type and pre-treatment versus post-treatment evaluation probably also account for different numbers of false-positive and false-negative results across the studies ${ }^{20,26,33,37}$. In support, a higher proportion of false positives, a measure of over-interpretation, was observed for suspicious LNs among women; in addition, some evidence for prior cancer history marginally affecting subjective suspicion was also noted. Consequently, the addition of sex and age to subjective impression considerably improved diagnostic accuracy and specificity, principally through reclassification of suspicious LNs. A trade-off between the specificity (+24\%) and sensitivity $(-10 \%)$ was noted, with the false negatives mostly confined to hematologic neoplasms. Otherwise, the combination of independent morphological and demographic factors, as selected through multivariate (MARS) analysis, further increased diagnostic accuracy through judiciously increased dimensionality, without adversely affecting the specificity or sensitivity. Non-linear relations and variable cut-off values were common, important and often model-specific, a finding that may help inform the debate on their biologic and diagnostic value.

The limitations of this study were as follows: I) modest size; II) inability to control for several potentially significant covariates; III) independent replication of the findings is required, but missing; IV) we did not have another independent examiner for interindividual comparison; V) there was no histologic verification of a LN; and VI) the results might differ by classification/regression method.

In conclusion, morphological characteristics of the LN play a significant role in predicting malignancy, but no single characteristic has the absolute discriminative power. The subjective impression exceeds diagnostic accuracy of other individual morphological features. The combination of morphological characteris- 
tics and demographic features can increase diagnostic accuracy, but a compromise between the sensitivity and specificity of the final model is often inevitable.

\section{Acknowledgments}

We thank Prof. S. Kurbel and Dr. Z. Dragić Arunasalam, $\mathrm{MD}$, for valuable comments on previous versions of the manuscript.

\section{References}

1. Jemal A, Bray F, Center MM, Ferlay J, Ward E, Forman D. Global cancer statistics. CA Cancer J Clin. 2011 Mar-Apr; 61(2):69-90. doi: 10.3322/caac.20107

2. Torre LA, Bray F, Siegel RL, Ferlay J, Lortet-Tieulent J, Jemal A. Global cancer statistics, 2012. CA Cancer J Clin. 2015 Mar;65(2):87-108. doi: 10.3322/caac.21262

3. Znaor A. Registar za rak. Hrvat Časopis Za Javno Zdr [Internet]. 2014 Apr 30;7(28). Available from: http://hcjz.hr/index. $\mathrm{php} / \mathrm{hcj} / \mathrm{article} / \mathrm{view} / 289$. (in Croatian)

4. Norling R, Buron BMD, Therkildsen MH, Henriksen BM, von Buchwald C, Nielsen MB. Staging of cervical lymph nodes in oral squamous cell carcinoma: adding ultrasound in clinically lymph node negative patients may improve diagnostic work-up. PLoS One. 2014 Mar 20;9(3):e90360. doi: 10.1371/ journal.pone.0090360

5. Ahuja AT, Ying M, Ho SY, Antonio G, Lee YP, King AD, et al. Ultrasound of malignant cervical lymph nodes. Cancer Imaging. 2008 Mar 25;8:48-56. doi: 10.1102/1470-7330.2008.0006

6. Esen G. Ultrasound of superficial lymph nodes. Eur J Radiol. 2006 Jun;58(3):345-59. http://dx.doi.org/10.1016/j.ejrad.2005. 12.039

7. Dudea SM, Lenghel M, Botar-Jid C, Vasilescu D, Duma M. Ultrasonography of superficial lymph nodes: benign vs. malignant. Med Ultrason. 2012 Dec;14(4):294-306.

8. Whitman GJ, Lu TJ, Adejolu M, Krishnamurthy S, Sheppard D. Lymph node sonography. Ultrasound Clin. 2011 Jul; 6(3):369-80. doi:10.1016/j.cult.2011.05.005

9. De Kerviler E, de Bazelaire C, Mounier N, Mathieu O, Brethon $\mathrm{B}$, Brière $\mathrm{J}$, et al. Image-guided core-needle biopsy of peripheral lymph nodes allows the diagnosis of lymphomas. Eur Radiol. 2007 Mar;17(3):843-9. doi: 10.1007/s00330-0060393-0

10. Hehn ST, Grogan TM, Miller TP. Utility of fine-needle aspiration as a diagnostic technique in lymphoma. J Clin Oncol. 2004 Aug 1;22(15):3046-52. doi: 10.1200/JCO.2004.02.104

11. Landgren O, Porwit MacDonald A, Tani E, Czader M, Grimfors $\mathrm{G}$, Skoog L, et al. A prospective comparison of fine-needle aspiration cytology and histopathology in the diagnosis and classification of lymphomas. Hematol J. 2004;5(1):69-76. doi: 10.1038/sj.thj.6200316
12. Friedman JH. Multivariate adaptive regression splines. Ann Stat. 1991;19(1):1-67.

13. Milborrow S. Derived from mda:mars by T. Hastie and R. Tibshirani. Earth: Multivariate Adaptive Regression Splines. R package version 4.4 .9 [software]. 2017 Feb 20 [cited 2017 Apr 07].Available from: https://CRAN.R-project.org/package=earth

14. R Core Team. R: A language and environment for statistical computing. R Foundation for Statistical Computing. Version 3.3.2 [software]. 2016 Oct 31 [cited $2017 \mathrm{Feb} 19$ ]. Available from: http://www.R-project.org/

15. Hastie T, Tibshirani R, Buja A. Flexible discriminant analysis by optimal scoring. J Am Stat Assoc. 1994;89(428):1255-70.

16. Mohseni S, Shojaiefard A, Khorgami Z, Alinejad S, Ghorbani A, Ghafouri A. Peripheral lymphadenopathy: approach and diagnostic tools. Iran J Med Sci.2014 Mar;39(2 Suppl):158-70.

17. Kunitz G. An approach to peripheral lymphadenopathy in adult patients. West J Med. 1985 Sep;143(3):393-6.

18. Vasilj A, Kojić Katović S. Fine-needle aspiration cytology of head and neck lymph nodes in a ten-year period - single center experience. Acta Clin Croat. 2015 Sep;54(3):315-8.

19. Misra D, Panjwani S, Rai S, Misra A, Prabhat M, Gupta P, et al. Diagnostic efficacy of color Doppler ultrasound in evaluation of cervical lymphadenopathy. Dent Res J (Isfahan). 2016 MayJun;13(3):217-24.

20. Raja Lakshmi C, Sudhakara Rao M, Ravikiran A, Sathish S, Bhavana SM. Evaluation of reliability of ultrasonographic parameters in differentiating benign and metastatic cervical group of lymph nodes. ISRN Otolaryngol. 2014 Apr 17;2014: 238740. doi: 10.1155/2014/238740

21. Catalano O. Critical analysis of the ultrasonographic criteria for diagnosing lymph node metastasis in patients with cutaneous melanoma: a systematic review. J Ultrasound Med. 2011 Apr;30(4):547-60. doi: 10.7863/jum.2011.30.4.547

22. Machado MR, Tavares MR, Buchpiguel CA, Chammas MC. Ultrasonographic evaluation of cervical lymph nodes in thyroid cancer. Otolaryngol Head Neck Surg. 2017 Feb;156(2):263-71. doi: 10.1177/0194599816676472

23. Ghafoori M,Azizian A, Pourrajabi Z, Vaseghi H.Sonographic evaluation of cervical lymphadenopathy; comparison of metastatic and reactive lymph nodes in patients with head and neck squamous cell carcinoma using gray scale and Doppler techniques. Iran J Radiol. 2015 Jul 22;12(3):e11044. doi: 10.5812/ iranjradiol.11044

24. Ahuja AT, Ying M. Sonographic evaluation of cervical lymph nodes. AJR Am J Roentgenol. 2005 May;184(5):1691-9. doi: 10.2214/ajr.184.5.01841691

25. Ogassavara B, Tucunduva Neto RR, de Souza RR, Tucunduva MJ. Ultrasound evaluation of the morphometric patterns of lymph nodes of the head and neck in young and middle-aged individuals. Radiol Bras. 2016 Jul-Aug;49(4):225-8. doi: 10.1590/0100-3984.2015.0002

26. Giacomini CP, Jeffrey RB, Shin LK. Ultrasonographic evaluation of malignant and normal cervical lymph nodes. Semin 
Ultrasound CT MR. 2013 Jun;34(3):236-47. doi: 10.1053/j. sult.2013.04.003

27. Cui XW, Hocke M, Jenssen C, Ignee A, Klein S, SchreiberDietrich D, et al. Conventional ultrasound for lymph node evaluation, update 2013. Z Gastroenterol. 2014 Feb;52(2): 212-21. doi: 10.1055/s-0033-1356153

28. Ying M, Bhatia KS, Lee YP, Yuen HY, Ahuja AT. Review of ultrasonography of malignant neck nodes: greyscale, Doppler, contrast enhancement and elastography. Cancer Imaging. 2014 Jan 6;13(4):658-69. doi: 10.1102/1470-7330.2013.0056

29. Podkrajsek M, Music MM, Kadivec M, Zgajnar J, Besic N, Pogacnik A, et al. Role of ultrasound in the preoperative staging of patients with breast cancer. Eur Radiol. 2005 May;15(5): 1044-50. doi: 10.1007/s00330-004-2545-4

30. Chammas MC, Macedo TA, Lo VW, Gomes AC, Juliano A, Cerri GG. Predicting malignant neck lymphadenopathy using color duplex sonography based on multivariate analysis. J Clin Ultrasound. 2016 Nov 12;44(9):587-94. doi: 10.1002/jcu.22380

31. Khanna R, Sharma AD, Khanna S, Kumar M, Shukla RC. Usefulness of ultrasonography for the evaluation of cervical lymphadenopathy. World J Surg Oncol. 2011 Feb 28;9:29. doi: 10.1186/1477-7819-9-29

32. Lee B, Lim AK, Krell J, Satchithananda K, Coombes RC, Lewis JS, et al. The efficacy of axillary ultrasound in the detec- tion of nodal metastasis in breast cancer. AJR Am J Roentgenol. 2013 Mar;200(3):W314-20. doi: 10.2214/AJR.12.9032

33. Choi YJ, Ko EY, Han BK, Shin JH, Kang SS, Hahn SY. Highresolution ultrasonographic features of axillary lymph node metastasis in patients with breast cancer. Breast. 2009 Apr;18 (2):119-22. doi: 10.1016/j.breast.2009.02.004.

34. Dangore SB, Degwekar SS, Bhowate RR. Evaluation of the efficacy of colour Doppler ultrasound in diagnosis of cervical lymphadenopathy. Dentomaxillofac Radiol. 2008 May;37(4): 205-12. doi: $10.1259 / \mathrm{dmfr} / 57023901$

35. Voit C, Van Akkooi ACJ, Schäfer-Hesterberg G, Schoengen A, Kowalczyk K, Roewert JC, et al. Ultrasound morphology criteria predict metastatic disease of the sentinel nodes in $\mathrm{pa}^{-}$ tients with melanoma. J Clin Oncol Off J Am Soc Clin Oncol. 2010 Feb 10;28(5):847-52. doi: 10.1200/JCO.2009.25.7428

36. Aggarwal A, Daniel MJ, Singh S, Patil P, Hindustanwala F, Kaushik SV. Nodal vascularity as an indicator of cervicofacial metastasis in oral cancer: a Doppler sonographic study. Niger Med J. 2014 Jul;55(4):299-305. doi: 10.4103/0300-1652.137189 .

37. Catalano O, Setola SV, Vallone P, Raso MM, D'Errico AG. Sonography for locoregional staging and follow-up of cutaneous melanoma: how we do it. J Ultrasound Med. 2010 May; 29(5):791-802. doi: 10.7863/jum.2010.29.5.791

Sažetak

\title{
VRIJEDNOST MJERLJIVIH I NEMJERLJIVIH ZNAČAJKA ULTRAZVUČNOG PRIKAZA LIMFNIH ČVOROVA U OTKRIVANJU ZLOĆUDNOG ZAUZEĆA
}

\author{
T. Rotim, B. Kristek, T. Turk, D. Kretić, M. Perić, I. Pǔseljić, T. Pandurović i M. Štefanić
}

Cilj istraživanja bio je odrediti dijagnostičku vrijednost i korisnost odabranih morfoloških značajka u predviđanju malignosti limfnog čvora (LČ) upotrebom B-moda, Dopplerova ultrazvuka i multivarijatnih postavka u tercijarnom radiološkom referentnom centru. U 123 bolesnika je učinjena ultrazvučno vođena aspiracijska punkcija i citološka analiza LČ vrata, pazuha i prepona. Svaki LČ je opisan uzdužnim/L i poprečnim/T promjerom, oblikom, rubom, ehogenošću, debljinom kore, vaskularizacijom i subjektivnim dojmom pregledavatelja. Unutar ograničenja citološke analize, izmijenjen oblik i vaskularizacija su imali visoku specifičnost i pozitivnu prediktivnu vrijednost $(>80 \%)$, dok je subjektivni dojam imao visoku osjetljivost i negativnu prediktivnu vrijednost $(100 \%)$ za malignost. Optimalne granične vrijednosti za različite značajke LČ dobivene analizom ROC su bile $23 \mathrm{~mm}$ za uzdužni promjer, $11 \mathrm{~mm}$ za poprečni promjer, 2,19 za omjer L/T i 5,1 mm za maksimalnu debljinu korteksa. U multivarijatnoj analizi (adaptive regression splines, $\mathrm{n}=108$ ) dodatak uzdužnog promjera, omjera L/T, dobi i spola semikvalitativnim obilježjima LČ značajno je povećao dijagnostičku točnost (88\%), osjetljivost (rubovi + vaskularizacija, 87\%) i specifičnost (subjektivni dojam, 83\%) konačnog dijagnostičkog modela. U zaključku, kombinacija morfoloških i demografskih značajka može poboljšati dijagnostičku točnost, obično uz kompromis između osjetljivosti i specifičnosti prediktivnog modela. Učinkovitost može ovisiti o razini stručnosti i institucionalnim postavkama.

Ključne riječi: Limfni čvorovi - anomalije; Ultrasonografija; Biopsija tankom iglom; Citodijagnostika; Prediktivna vrijednost testova; Hrvatska 